\title{
Hasil Musyawarah Keagamaan Kongres Ulama Perempuan Indonesia I dalam Sudut Pandang Ekonomi
}

\author{
Singgih Muheramtohadi \\ Fakultas Ekonomi dan Bisnis Islam \\ UIN Walisongo Semarang \\ email:singgih_muheramtohadi@walisongo. \\ ac.id
}

\begin{abstract}
Economic point of view is needed to view all human activities on the effort to meet the needs or profit collection. On this paper, economic approach to view the three big issues was resulted by the conference in Indonesia's First Female Muslim Clerics Congress in Cirebon. These three issues consist of sexual violence, child marriage, and natural damage. In these conferences, view these three big problems in Islamic teaching. This paper tries to view these problems in economic basic view. The three big problems not only the problem of ethic merely these about the economic problem because the economic factors play a big role in these problems. This paper will discuss the problems with the description of the result of the conference, and analyze it with an economic approach. Mostly the destroyers of the environment are motivated by economic behavior. Economic behavior also plays a role in most of the child marriage cases and in many of sexual violence cases.
\end{abstract}

$\begin{array}{ll}\text { Keywords: Indonesia's female muslim clerics congress; } & \\ \text { economic approach; result of congress }\end{array}$

Abstrak: Sudut pandang ekonomi diperlukan untuk melihat segala aktivitas manusia dari usaha pemenuhan kebutuhan ataupun mengumpulkan laba. Pada artikel ini, pendekatan ekonomi digunakan untuk melihat tiga isu yang dihasilkan dalam Musyawarah Kongres Ulama Perempuan Indonesia I di Cirebon. Ketiga isu tersebut adalah: kekerasan seksual, pernikahan anak, dan kerusakan alam. Dalam musyawarah tersebut, ketiga isu besar tersebut dilihat dengan sudut pandang norma keislaman. Artikel ini mencoba untuk melihatnya dari sudut pandang ekonomi. Ketiga masalah besar tersebut sebenarnya bukan hanya masalah etika melainkan juga masalah ekonomi, karena faktor ekonomi juga berperan penting di dalam permasalahan ini. Artikel ini ini mengkaji permasalahan tersebut dengan mendeskripsikan hasil musyawarah kemudian menganalisanya dengan pendekatan ilmu ekonomi, terutama tentang perilaku ekonomi. Hampir semua perilaku merusak lingkungan termotivasi dari perilaku ekonomi. Perilaku ekonomi juga berperan dalam sebagian besar kasus pernikahan anak, dan dalam kasuskasus tertentu juga menjadi faktor dalam kekerasan seksual.

Kata Kunci: Kongres Ulama Perempuan Indonesia; pandangan ekonomi; hasil musyawarah 


\section{A. Pendahuluan}

Ulama identik dengan kaum lelaki. Kitab-kitab yang menjadi rujukan pesantren salaf adalah kitab yang disusun oleh kaum lelaki. Para umam almadhāhib adalah para lelaki, mereka adalah Imam Malik, Imam Muhammad Ibn Hanbal, Imam Abu Hanifah dan Imam Syafi'i. Begitu juga para pemuka ilmu Hadis juga didominasi oleh para lelaki, seperti Bukhari, Muslim, Ahmad, Baihaqi, dan sebagainya. Walaupun dalam sejarah Islam sendiri juga dikenal nama Siti 'Aisyah, istri Nabi, sebagai salah satu perawi terbesar dalam hadishadis Nabi.

Dominasi teks kitab keagamaan di Indonesia juga didominasi oleh para kaum pria. Pimpinan Majelis Ulama, dan para dai di indonesia juga didominasi oleh kaum lelaki. Meskipun pada perkembangan terakhir muncul pengembangan pesantren keputrian, dimana dipimpin oleh seorang perempuan (biasanya istri para kyai pengasuh pesantren). Tetapi pada umumnya, peran ulama perempuan belum banyak diketahui. Masyarakat pada umumnya lebih mudah menemukan biografi ulama pria daripada perempuan. ${ }^{1}$

Minimnya peran ulama perempuan ini berbanding terbalik dengan semakin banyaknya permasalahan yang dihadapi oleh para perempuan. Di sisi lainnya, metodologi ilmu pengetahuan di bidang humaniora modern, menempatkan pelaku sebagai subyek utama, sehingga penelitian bercorak fenomenologi diberikan tempat. ${ }^{2}$ Relevansinya di sini adalah permasalahan keperempuanan maka sudut pandang perempuan itu harus diberikan tempat utama. Di sinilah urgensi Kongres Ulama Perempuan Indonesia I ini diselenggarakan.

Kongres ini menghasilkan tiga isu besar yaitu tentang kekerasan seksual, pernikahan anak, dan kerusakan alam. ${ }^{3}$ Ketiga isu ini dibahas dengan sudut

1Jajat Burhanudin, ed., Ulama Perempuan Indonesia (Gramedia, 2002), 249; Baca juga: Amelia Fauzia, Jajat Burhanuddin, and Oman Fathurahman, Tentang Perempuan Islam: Wacana dan Gerakan Uakarta: Gramedia Pustaka Utama bekerja sama dengan Pusat Pengkajian Islam dan Masyarakat (PPIM), UIN Jakarta, 2004).

${ }^{2}$ Suwardi Endraswara, Metode, Teori, Teknik Penelitian Kebudayaan (Yogyakarta: Pustaka Widyatama, 2006), 67.

3Yusuf Asyari, "Nih 3 Rekomendasi Hasil Kongres Ulama Perempuan Indonesia," JawaPos.com Berita di Sekitar Anda, 2017, diakses pada tanggal 30 Juni 2017, https://www.jawapos.com/jpgtoday/29/04/2017/nih-3-rekomendasi-hasil-kongres-ulama-perempuan-indonesia. 
pandang normatif, atau sudut pandang yang didasarkan atas benar atau salah suatu perbuatan, baik lewat norma agama, norma hukum ataupun norma kesusilaan. Tulisan ini berusaha untuk melengkapi sudut pandang normatif tersebut dengan sudut pandang ekonomi. Sehingga ketiga isu tersebut juga menjadi permasalahan tidak hanya menyangkut masalah fiqh perempuan, melainkan juga permasalahan di bidang ekonomi.

Sehingga penelitian ini akan menjawab pertanyaan, apa keterkaitan antara isu kekerasan seksual dengan permasalahan ekonomi, apa keterkaitan antara kerusakan alam dengan permasalahan ekonomi, dan apa keterkaitan antara pernikahan dini dengan permasalahan ekonomi.

\section{B. Hasil Musyawarah dan Rekomendasi Ulama Perempuan Indonesia}

Untuk pertama kalinya para Ulama Perempuan Indonesia mengadakan Kongres Ulama Perempuan Indonesia pada tanggal 25 sampai 27 April 2017 yang diselenggarakan di Pondok Pesantren Kebon Jambu Al-Islami, Cirebon, Jawa Barat. Kongres ini dihadiri oleh ribuan ulama perempuan dari seluruh nusantara. Pada kongres ini, KUPI (Kongres Ulama Perempuan Indonesia) menghasilkan tiga isu besar, yaitu isu kekerasan seksual, isu pernikahan anak, dan isu kerusakan alam. ${ }^{4}$

Tiga isu di atas, menurut KUPI, adalah haram dilakukan. Sehingga semua pihak harus mengupayakan untuk mengurangi atau mencegah terjadinya ketiga hal di atas (kekerasan seksual, pernikahan anak dan kerusakan alam), dan negara harus hadir untuk mencegahnya.

Beberapa rekomendasi yang diberikan oleh Kongres Ulama Perempuan tentang Pernikahan Anak di antaranya adalah: 1) Memastikan adanya regulasi (peraturan) di tingat nasional untuk mencegah, menangani atau penghapusan pernikahan anak. 2) Melakukan amandemen UU No 1 Tahun 1974 yang membolehkan pernikahan anak yang berusia 16 tahun, dan hendaknya dirubah menjadi batas minimal 18 tahun. 3) Memastikan instansi terkait (KUA, Pengadilan Agama, Pengadilan Negeri, Pemerintahan Desa/Kelurahan), untuk

\footnotetext{
${ }^{4}$ Satori, Rosidin, dan Hasani, Liputan Media Kongres Ulama Perempuan Indonesia (Cirebon: KUPI, 2017), 156.
} 
tidak mengurus atau mencatatkan praktek pernikahan anak secara legal. 4) Memastikan pemerintahan dari pusat sampai ke desa/kelurahan memfasilitasi program pencegahan pernikahan anak. 5) Kementerian Pendidikan agar memastikan wajib belajar bagi anak sebagai upaya pencegahan pernikahan anak. 6) Kemeninfo menutup situs-situs porno. ${ }^{5}$

Pertimbangan para ulama perempuan di atas adalah banyaknya kasus pernikahan anak, terutama di wilayah pedesaan. Dalam Undang-undang sendiri, batas seorang perempuan menikah adalah 16 tahun, dan pihak KUA asalkan sesuai dengan syarat dan izin orangtua, maka mereka harus mengizinkan praktek pernikahan dini. Sebagian besar praktek pernikahan dini diakibatkan oleh remaja yang putus sekolah. Hal ini dapat dilihat dari tingkat pendidikan akhir yang mereka tempuh di sekolah. Sehingga, KUPI merekomendasikan agar Kementerian Pendidikan ikut berperan aktif untuk memastikan wajib belajar. Selain itu, faktor pernikahan dini diakibatkan oleh kenakalan remaja. Hal ini semakin banyaknya para remaja yang mempunyai kesempatan untuk mengakses situs-situs porno, sehingga KUPI juga merekomendasikan kepada Kementerian Komunikasi dan Informatika untuk ikut andil dengan menutup situs-situs porno.

Sedangkan rekomendasi tentang kerusakan alam, sebagaimana hal-hal berikut ini: 1) Pembuatan instrumen kebijakan, program khusus, dan pembiayaan yang memadai untuk menjamin kelestarian alam. 2) Mengatasi kerentanan perempuan dan anak-anak dari dampak kerusakan alam. 3) Menghapus segala bentuk perundangan yang berpotensi meningkatkan kerusakan ekosistem lingkungan hidup. 4) Memberikan sanksi terhadap para pelaku usaha yang merusak alam. 5) Mengembangkan penelitian/riset tentang teknologi ramah lingkungan, serta inovasi untuk memperkuat peran perempuan sebagai subyek pelestari lingkungan alam. ${ }^{6}$

Pertimbangan Kongres Ulama Perempuan Indonesia (KUPI) di atas berdasarkan pada fakta terjadinya perusakan lingkungan alam, karena faktor ekonomis, yaitu peningkatan profit usaha bagi pihak-pihak yang ber2017), 116

${ }^{5}$ Tim KUPI, Dokumen Resmi Proses dan Hasil Kongres Ulama Perempuan Indonesia (Cirebon: KUPI, 6Tim KUPI, 143-44. 
kepentingan. Perusakan alam bisa terjadi di hutan (penebangan), di laut (dengan pencemaran air limbah atau perusakan terumbu karang), sampai di lingkungan pedesaan (berupa industri yang menghasilkan limbah tanpa mempedulikan AMDAL).

Sedangkan tentang kekerasan seksual, merekomendasikan kepada pemerintah hal-hal berikut ini: 1) Eksekutif bersama dengan legislatif segera mengeluarkan Undang-undang untuk pemenuhan hak-hak korban kekerasan seksual, serta dapat mencegah perilaku kekerasan seksual pada perempuan. 2) Memastikan agar layanan bagi perempuan korban kekerasan seksual diberikan pelayanan yang semaksimal mungkin tanpa diskriminasi. 3) Pemerintah menyediakan pegawai yang handal dan memiliki perspektif dari sudut pandang korban dan HAM.7

Pada poin tentang kekerasan seksual di atas, didasarkan pertimbangan semakin banyaknya kasus kekerasan seksual yang terjadi dengan korban kebanyakan adalah perempuan. Tingginya kasus kekerasan seksual tersebut tidak diimbangi dengan pelayanan yang maksimal. Hal ini ditambah dengan ketidakberdayaan SDM/pegawai pemerintahan yang bisa bergerak cepat untuk menuntaskan kasus-kasus pelecehan seksual. Mereka seolah tidak tahu SOP. sehingga kekerasan seksual tidak semakin berkurang malah semakin bertambah. Sehingga, solusi terhadap kasus pelecehan seksual adalah dengan mengeluarkan perundangan yang melindungi perempuan dari kasus kekerasan seksual.

\section{Ekonomi dan Pernikahan Usia Dini Anak Perempuan \\ Pandangan Kongres Ulama Perempuan terhadap Pernikahan Dini}

Pernikahan Anak merupakan salah satu tema penting yang dibahas dalam Kongres Ulama Perempuan Indonesia I (KUPI I). Permasalahan ini menjadi tema yang penting dibicarakan karena berdasarkan Data dari Unicef tahun 2016, Indonesia merupakan salah satu dari tujuh negara dngan jumlah pernikahan anak tertinggi sedunia. Menurut data yang dikeluarkan oleh Unicef tersebut, satu dari empat perempuan di Indonesia menikah berusia di bawah 18 tahun.

7Tim KUPI, 91. 
Tabel 1.

Lima Provinsi dengan Tingkat Pernikahan Anak Tertinggi di Indonesia

\begin{tabular}{clc}
\hline No. & \multicolumn{1}{c}{ Nama Provinsi } & Persentase \\
\hline 1 & Sulawesi Barat & $34,22 \%$ \\
2 & Kalimantan Selatan & $33,68 \%$ \\
3 & Kalimantan Tengah & $33,56 \%$ \\
4 & Kalimantan Barat & $32,21 \%$ \\
5 & Sulawesi Tengah & $31,91 \%$ \\
\hline
\end{tabular}

Menurut data Balai Pusat Statistik (BPS) tahun 2015, rata-rata pernikahan anak di Indonesia berada pada angka 22,82\%. Data lima provinsi dengan tingkat pernikahan anak tertinggi di Indonesia dapat dilihat pada Tabel $1 .^{8}$

Perbandingan pernikahan anak (di bawah usia 18 tahun) kebanyakan terjadi di wilayah pedesaan dengan jumlah $27,11 \%$ dan di wilayah perkotaan dengan jumlah 17,09\%. Adapun faktor-faktor penyebab pernikahan anak dapat dijumpai pada beberapa sebab berikut ini: ${ }^{9}$ 1) kehamilan tak diinginkan (KTD), 2) perjodohan paksa. 3) putus sekolah. 4) keterbatasan biaya. 5) kemandirian ekonomi. 6) seksualitas tak terkontrol. 7) justifikasi agama.

Menurut data yang bersumber dari BPS 2016, Kongres Ulama Perempuan menyatakan bahwa 85\% dari anak yang menikah tidak melanjutkan sekolah mereka, atau seorang anak perempuan yang menikah, kemungkinan enam kali lebih besar untuk tidak menyelesaikan pendidikan mereka (Unicef 2016), sedangkan orang yang berpendidikan rendah mempunyai angka kematian bayi yang tiga kali lebih besar daripada ibu yang berpendidikan menengah atau tinggi. Dan pernikahan Anak berakhir dengan perceraian mempunyai grafis tinggi berdasarkan data yang dilansir oleh Indonesia Demographic and Health Survey tahun 2012 yaitu sebanyak $22 \% .^{10}$

Dalam Kongres Ulama Perempuan I tersebut, pelarangan pernikahan anak didasarkan banyak pertimbangan, baik dalil naqli, dalil 'aqli atau pertimbangan yuridis. Dalam pertimbangan naqli, KUPI I menggunkaan QS. al-Rūm 21, yang memuat pesan bahwa tujuan pernikahan adalah untuk mewujudkan ke-

${ }^{8}$ Tim KUPI, 101.

${ }^{9}$ Tim KUPI, 101-2.

10Tim KUPI, 103. 
tenangan jiwa, dan kasih sayang antara dua pasang suami dan istri. ${ }^{11}$ Dalam penikahan, seharusnya tidak meninggalkan keturunan yang lemah, ${ }^{12}$ dan keluarga sebagai unit terkecil sebagai pembangun ummat yang terbaik yang senantiasa menyeru pada perbuatan makruf dan mencegah kemungkaran.13

Para ulama Mutaqadimin sejak dari semula juga telah mengharamkan pernikahan anak, atau mereka yang berusia tidak baligh. Sebagaimana tokoh ulama salaf Abdulah Ibn Syubrumah, Abu Bakar al-Aslam, dan Utsman al-Batti. Ibn Hazm juga menukil pernyataan Ibn Syubrumah yang mengharamkan pernikahan usia anak. Imam al-Syaukani mengatakan bahwa pernikahan anak yang tidak membawa kemaslahatan maka negara wajib membatalkannya. Sedangkan Ibn Hajar al-Atsqalani menyatakan bahwa pernikahan terkait dengan kemampuan ekonomi, fisik, maupun biologis seseorang. Seseorang yang tidak mampu, disarankan untuk berpuasa. ${ }^{14}$

\section{Analisa Ekonomi tentang Pernikahan Anak}

Hasil Musyawarah Kongres Ulama Perempuan Indonesia I mempunyai pandangan moderat terhadap pernikahan anak. Mereka menolak jenis pernikahan anak, dengan mengambil pendapat para ulama salaf yang melarang pernikahan anak. Dalam fiqh Islam sendiri terdapat istilah 'balaghun nikah' sebagai suatu istilah yang berasal dari al-Qur'an yang menyatakan tentang kecukupan usia bagi seseorang untuk melakukan pernikahan. Pendekatan yang dipakai dalam Musyawarah Kongres Ulama Perempuan Indonesia ini, masih menggunakan sudut pandang normatif. Yaitu mengkaji pernikahan Anak dengan mengacu pada pembahasan norma, baik norma keagamaan maupun norma hukum. Dan tulisan ini berusaha untuk melengkapi hasil musyawarah tersebut dengan mengkaji dengan sudut pandang ekonomi.

Terdapat keterkaitan erat antara pernikahan dini dengan ekonomi. Hal ini dapat diihat dari masih maraknya pernikahan dini, yang masih banyak terjadi di Pulau Jawa, terutama di pedesaan. Menurut pendapat yang dinukil dari Musyawarah para ulama perempuan tersebut, hal ini dikarenakan mengecilnya

"QS. al-Rūm: 21.

${ }^{12}$ QS. al-Nisā': 9.

${ }^{13}$ QS. Āli 'Imrān: 110.

${ }^{14}$ Tim KUPI, 109. 
kepemilikan lahan pertanian, sehingga mereka tidak lagi memiliki penghasilan dari lahan. ${ }^{15}$ Dalam kondisi seperti ini lah mereka menikahkan anak perempuan mereka. Sehingga 'beban ekonomi' mereka berkurang. Tetapi, dampak pernikahan dini tidak menjadikan keluarga lebih sejahtera, malah meningkatkan angka kemiskinan. Menurut data yang dilansir dari BPS angka kemiskinan dari keluarga yang menikah dini, sebanyak 29,9\%. Sehingga di sini, faktor pemicu dari pernikahan anak (atau sering pula disebut dengan pernikahan dini), dapat terjadi karena faktor ekonomi, dan mempunyai dampak ekonomi.

Menurut Tim BPS bahwa perkawinan anak memiliki keterkaitan dengan kemiskinan. Kemiskinan mendorong orangtua untuk menikahkan anaknya. Karena biaya pendidikan dirasa semakin mahal. Berdasarkan data Susenas Tahun 2012, bahwa perempuan berusia 20-24 tahun yang melakukan pernikahan di usia anak, 40,1\% di antaranya tinggal di hunian yang tidak layak, dan 29,9\% di antaranya mempunyai pengeluaran yang sangat rendah. Sehingga, terdapat korelasi positif antara pernikahan di usia anak dengan kemiskinan.16

Berdasarkan data Susenas Tahun 2012 pernikahan anak sangat berkaitan dengan putusnya sekolah. Sebanyak 46,7\% anak yang melakukan pernikahan dini tidak lulus dari sekolah dasar, 40,5\% diantaranya adalah lulus SD. Sehingga didapatkan angka lebih dari $87 \%$ dari anak yang melakukan pernikahan dini adalah anak yang maksimal hanya lulusan SD. Sehingga, peran pendidikan gratis sangat penting untuk mengurangi angka pernikahan anak. Karena kebanyakan dari anak yang menikah dini, diakibatkan karena faktor kemiskinan dan faktor tingginya angka putus sekolah. ${ }^{17}$

Dari berbagai penelitian, didapatkan hasil bahwa semakin rendah tingkat ekonomi keluarga maka mempunyai peluang yang semakin tinggi untuk menikahkan anak di usia dini. Sebaliknya, semakin tinggi tingkat ekonomi keluarga, maka semakin rendah peluang untuk menikahkan anak di usia dini. Dan pada umumnya, pernikahan anak tersebut tidak lah memutuskan rantai kemiskinan.

${ }^{15}$ Satori, Rosidin, dan Hasani, Liputan Media Kongres Ulama Perempuan Indonesia, 101.

${ }_{16}^{6}$ Subdirektorat Statistik Rumah Tangga, Kemajuan yang Tertunda: Analisis Data Perkawinan Usia Anak di Indonesia (Jakarta: Badan Pusat Statistik, 2016), 36.

${ }^{17}$ Subdirektorat Statistik Rumah Tangga, 34. 
Ditinjau dari segi ekonomi, seorang ayah yang menikahkan anak perempuannya, maka ia akan menghemat pengeluaran. Jika orangtua anak perempuan, selama ini mengeluarkan uang sebanyak 1 juta rupiah untuk menghidupi anak-anaknya, maka dengan pernikahan salah seorang anaknya, maka pengeluaran rumah tangganya berkurang. Tetapi, jika angka pernikahan anak sangat tinggi, maka kesempatan bekerja bagi anak perempuan tersebut menjadi sangat rendah. Sehingga, angka Produk Domestik Bruto (PDB) yang dihasilkan oleh seluruh warga negara indonesia juga semakin berkurang.

\section{Ekonomi dan Kekerasan Seksual}

\section{Pandangan Kongres Ulama Perempuan terhadap Kekerasan Seksual}

Kekerasan seksual merupakan tema yang paling penting yang diangkat dalam Kongres Ulama Perempuan Indonesia. Mengingat kekerasan seksual terhadap perempuan tergolong sangat tinggi di Indonesia. Menukil dari laporan Komnas Perempuan Tahun 2012, kekerasan terhadap perempuan terjadi dengan tingkat rata-rata tiap jam terjadi 3 perempuan yang menjadi korban kekerasan seksual. Atau tiap hari terjadi 36 korban kekerasan seksual yang dialami perempuan. ${ }^{18}$

Sementara itu berdasarkan sumber BPS - SPHPN tahun 2016, Kongres Ulama Perempuan juga mencatat bahwa kekerasan yang dialami perempuan dari pasangan mereka juga menunjukkan grafis yang relatif tinggi. Bahwa 2 dari 11 perempuan yang pernah ataupun sedang masa pernikahan, pernah mengalami kekerasan atau seksual dari suami mereka. Sedangkan perempuan menjadi korban kejahatan perkosaan, sebanyak 1.389 kasus, dan 1.266 korban pencabulan, dengan mayoritas pelaku adalah pacar.19

Menurut Kongres Perempuan, status perempuan adalah sebagai anak Adam, dimana mereka berhak dimuliakan. Status anak adam (manusia) ini tidak hanya meliputi laki-laki, melainkan juga perempuan. Mengambil QS. alIsrä': 70, menegaskan bahwa Allah telah mengangkut manusia dari daratan dan lautan dan memberikan mereka rezeki, dan melebihkan mereka satu sama

\footnotetext{
18"Hasil Musyawarah Keagamaan Kongres Ulama Perempuan Indonesia No. 01/MK-KUPI1/IV/2017 Tentang Kekerasan Seksual 2017" (Cirebon: KUPI, 2017).

${ }^{19}$ Tim KUPI, Dokumen Resmi Proses dan Hasil Kongres Ulama Perempuan Indonesia, 59.
} 
lainnya, serta meninggikan derajat mereka di atas derajat makhluk lainnya. Melakukan tindakan pelecehan terhadap perempuan, merupakan perbuatan yang dilarang sebagaimana yang difirmankan oleh Allah dalam QS. al-Nisā': 19 yaitu larangan untuk melakukan tindakan memaksa perempuan, menghalangi hak mereka, serta perintah untuk memperlakukan mereka dengan sebaikbaiknya. Karena seorang perempuan dan lelaki, diciptakan untuk saling tolong menolong (QS. al-Taubah: 71) untuk mengerjakan amal perbuatan terpuji. ${ }^{20}$

Dalam sejarah Islam tercatat, bahwa seorang tidak berhak menjadikan budak perempuannya sebagai pelacur. Karena di masa Jahiliyah, seorang majikan berhak untuk menjadikan budak nya sebagai pelacur, dan ia berhak menerima bagian dari mahar. Rasulullah sendiri dalam suatu hadisnya menyatakan bahwa ia melarang mengambil keuntungan dari penjualan anjing, mahar pelacuran, dan upah perdukunan. ${ }^{21}$

\section{Analisa Ekonomi terhadap Kasus Kekerasan Seksual}

Kongres Ulama Perempuan Indonesia (KUPI) mempunyai tujuan untuk meletakkan dasar kesepahaman bersama untuk mengatasi permasalahanpermasalahan yang dialami oleh para perempuan di Indonesia. Kesepahaman tersebut dikeluakan dalam wujud fatwa ataupun rekomendasi. Pengeluaran fatwa tersebut, sebagaimana disebutkan di atas, berdasarkan pertimbangan agama. Mereka menyajikan dalil, baik berasal dari al-Qur'an, al-Sunnah, Ijma' ataupun ulama yang mempunyai kompetensi di bidang fiqh.

Kasus kekerasan seksual ini, selain dikaji dari sudut pandang agama maupun moral, juga telah banyak dikaji lewat pandangan ilmu psikologi. Karena kekerasan seksual selalu melibatkan sisi emosional. Baik dari sisi korban maupun pelaku. Mereka mencoba untuk merumuskan berbagai hal, seperti motif pelaku, stabilitas emosional pelaku, dampak psikis bagi korban seperti depresi, trauma, stress, dan sebagainya. Karena jenis kekerasan seksual bermacam-macam, sehingga sulit untuk menggeneralisir bahwa smeua kekerasan seksual disebabkan hanya karena faktor tunggal.

\footnotetext{
${ }^{20}$ Tim KUPI, 61-162.

${ }^{21}$ Muhammad bin Ismāil bin Ibrāhīm bin al-Mughīrah al-Bukhāry, Șahīh al-Bukhāry (al-Maktabah al-Syamilah, n.d.), hd. no. 2277.
} 
Kasus kekerasan seksual dapat terjadi karena memang murni masalah psikologis, seperti seseorang yang tidak kuat menahan nafsu kemudian menculik dan memaksa seorang perempuan untuk melayani nafsunya. Tetapi ada kala nya, seorang korban kekerasan seksual (seperti pemerkosaan, misalnya), mereka menjadi korban karena ia memang secara posisi tidak berdaya untuk menolak ajakan seseorang karena faktor lingkungan sosial (sosiologis). Hal ini dapat dilihat dari maraknya kasus kekerasan seksual yang dialami oleh anak jalanan. Mereka pada umumnya, hidup mencari nafkah dan bersosialisasi dengan orang yang sama, dan mempunyai aturan yang rendah tentang seksualitas. $^{22}$

Faktor ekonomi, dapat ditemukan pada kasus pelacuran. Seperti yang terjadi di Pantai Samas, Silir di Solo, Pasar Kembang di Yogyakarta, dan beberapa lokalisasi pelacuran. Mereka rata-rata sebagai orang yang tidak mampu, dan menempuh jalan pelacuran untuk mencukupi kebutuhan sehari-hari. Sehingga motif mereka murni ekonomi. Sehingga, mereka bersedia 'dipaksa' oleh seorang atau beberapa orang untuk melakukan tindakan yang diinginkan oleh pihak yang membutuhkannya. Dari berbagai penelitian tentang pelacuran di berbagai wilayah ditemukan bahwa faktor dominan seorang menjadi PSK karena faktor ekonomi. Mereka sulit menemukan pekerjaan yang bisa mencukupi kebutuhan sehari-hari. ${ }^{23}$

Faktor ekonomi juga terdapat pada kasus dimana seorang perempuan yang mengalami kekerasan dalam rumah tangga (KDRT). KDRT biasanya seorang perempuan yang tidak memiliki penghasilan sendiri, atau semua penghasilan yang ia butuhkan beserta anaknya berasal dari suaminya. seorang perempuan yang mempunyai penghasilan, mempunyai independensi yang lebih besar daripada seorang perempuan yang tidak berpenghasilan. Seorang perempuan dalam posisi seperti ini sangat mudah mengalami kekerasan dalam rumah tangga. Karena manusia cenderung tergantung pada sumber penghasilan

\footnotetext{
${ }^{22}$ Aditya Kusumawati, Zahroh Shaluhiyah, dan Antono Suryoputro, "Tradisi Kekerasan Seksual sebagai Simbol Kekuasaan pada Anak Jalanan di Kota Semarang," Jurnal Promosi Kesehatan Indonesia 9, no. 1 (2016): 17-31, https://doi.org/10.14710/JPKI.9.1.17-31.

${ }^{23}$ Siti Munawaroh, "Pekerja Seks Komersial (PSK) di Wilayah Prambanan, Kabupaten Klaten, Jawa Tengah," Dimensia 4, no. 2 (2010): 69-82, https://journal.uny.ac.id/index.php/dimensia/article/ view/3433.
} 
ekonominya. Hal ini jelas berbeda dengan 'perempuan karir' yang mempunyai kemandirian. Seorang istri jarang melaporkan tindakan KDRT yang dilakukan pasangannya karena kuatir akan mengalami kesulitan dalam memenuhi kehidupan sehari-hari. ${ }^{24}$

Dalam beberapa kasus pelecehan seksual juga dialami oleh perempuan yang bekerja di tempat hiburan. Karena dalam tempat hiburan, memaksa mereka berpakaian seksi sehingga mengundang syahwat orang lain. bentuk pelecehan seksual ini bisa berupa sentuhan (meraba-raba), atau dapat berupa ucapan-ucapan. Orang yang menjadi korban pelecehan seksual ini sulit ditemukan pada orang yang mampu. Karena orang mampu, akan dapat membawa kasus ini di pengadilan atau membayar orang lain untuk membereskan urusannya. Selain itu kekerasan seksual kerap terjadi di masyarakat yang secara sosial ekonomi nya miskin. ${ }^{25}$ Selain itu, dampak ekonomi juga terjadi, jika seorang perempuan yang dilecehkan tersebut adalah perempuan pekerja. Produktivitas pekerjaannya akan terganggu, jika pelecehan terhadap beberapa pekerja perempuan dibiarkan maka akan terjadi penurunan moral pekerja sehingga mereka tidak lagi termotivasi dalam bekerja dan pada akhirnya akan menurunkan produktivitas. Kemungkinan sebuah badan usaha akan kehilangan beberapa karyawan perempuannya, jika pelecehan seksual terus menerus terjadi tanpa adanya usaha untuk menghentikannya.

Praktek kekerasan seksual lainnya adalah perbuatan menikahi perempuan hanya untuk kesenangan semata. Praktek ini sering dilakukan dengan model pernikahan siri. Perempuan menikah di bawah tangan tanpa persetujuan wali atau menikah di depan petugas KUA, dengan harapan bahwa si perempuan akan mendapatkan uang jaminan hidup, dan laki-laki mendapatkan kepuasan seksual. Dalam posisi seperti ini kedudukan perempuan sangat rentan, karena suami sirinya berhak meninggalkannya tanpa memberikan mahar apapun. Praktek seperti ini juga dikarenakan faktor ekonomi sehingga seorang perempuan rela menjadi istri siri.

\footnotetext{
${ }^{24}$ La Jamaa, "Perlindungan Korban Kekerasan dalam Rumah Tangga dalam Hukum Pidana Indonesia," Jurnal Cita Hukum 2, no. 2 (2014): 249-72, http://journal.uinjktac.id/index.php/ citahukum/article/view/1467.

${ }^{25}$ Muhammad Teja, "Kondisi Sosial Ekonomi dan Kekerasan Seksual pada Anak," Majalah Info Singkat Kesejahteraan Sosial, May 2016, 10.
} 
Faktor ekonomi juga dapat dilihat dari perdagangan manusia (human traficking), seorang penyedia perempuan mendapatkan fee dari aktivitas perdagangan. Sedangkan pihak korban, mereka membutuhkan pekerjaan. Sehingga, banyak perempuan yang jadi korban kasus penipuan. Mereka dijanjikan untuk dipekerjakan secara layak, tetapi pada akhirnya dipaksa untuk melacurkan diri. Perempuan yang menjadi korban perdagangan perempuan ini rata-rata berasal dari kalangan menengah ke bawah. Karena faktor ekonomi, mereka tidak dapat meneruskan pendidikan dan mendapatkan pekerjaan secara layak. Hampir semua faktor yang menjadi penyebab terjadinya human trafficking adalah masalah kemiskinan, karena permasalahan ini sangat sering terjadi pada masyarakat yang secara sosial ekonomi menengah ke bawah. ${ }^{26}$

Banyak sekali kasus yang terjadi, dimana seorang perempuan yang menjadi korban kekerasan seksual, pada hakikatnya terjadi karena ketidakberdayaannya dalam mencukupi kebutuhannya. Mereka rela diperlakukan kasar oleh pasangannya (KDRT), menjual diri kepada orang lain (prostitusi), tidak berdaya menghadapi pelecehan seksual, dan sebagainya. Sudut pandang ekonomi dalam melihat kasus kekerasan seksual ini jarang diperhatikan.

\section{E. Ekonomi dan Kerusakan Alam}

\section{Pandangan Kongres Ulama Perempuan terhadap Kerusakan Alam}

Salah satu isu utama yang dibahas dalam Kongres Ulama Perempuan Indonesia I adalah tentang kerusakan alam. Beberapa hal yang menjadi pertimbangan kenapa isu kerusakan alam menjadi bahan musyawarah oleh para ulama perempuan, berdasarkan hal-hal berikut ini: 1) Terdapat 721 kecamatan (di 102 Kabupaten/kota dan di 16 Provinsi) yang menjadi daerah terdampak langsung dari bencana kekeringan. 2) Laju penggundulan hutan (deforestisasi) di Indonesia mengalami tingkat pertumbuhan yang sangat tinggi, yaitu mencapai angka sampai 2 juta hektar per tahun, sehingga Indonesia menjadi negara dengan laju penggundulan hutan tertinggi se-dunia. 3) Terjadinya konflik agraria yang mengalami peningkatan dari tahun ke tahun. Misalnya di

\footnotetext{
${ }^{26}$ Everd Scor Rider Daniel, Nandang Mulyana, dan Budhi Wibhawa, "Human Trafficking di Nusa Tenggara Timur," Share: Social Work Journal 7, no. 1 (2017): 21, https://doi.org/10.24198/ share.v7i1.13808.
} 
tahun 2016, terjadi konflik agraria yang melibatkan 86.745 keluarga dengan luasan tanah dengan total sebesar 1.265.027 Ha. ${ }^{27}$

Kongres ini menyimpulkan bahwa terjadinya perusakan alam akan berdampak besar terhadap perempuan dan anak-anak. Menurut hasil Musyawarah Keagamaan Kongres Ulama Perempuan Indonesia No. 03/MK-KUPI1/IV/2017 tentang Perusakan Alam, terdapat korelasi positif antara perusakan alam dan hilangnya kemampuan perempuan terhadap diri mereka sendiri maupun terhadap sumberdaya alam. Menurut studi, dampak kerusakan lingkungan ini menyebabkan beban yang ditanggung oleh perempuan menjadi beberapa kali lipat daripada yang ditanggung oleh seornag lelaki. Sehingga memunculkan beberapa permasalahan, seperti semakin banyaknya angka putus sekolah di kalangan perempuan, terganggunya kesehatan reproduksi, dan semakin banyaknya angka kematian ibu dan bayi waktu melahirkan. Ketidakmampuan ini disertai dengan anggapan-anggapan negatif terhadap perjuangan para perempuan dalam memperjuangkan kepentingannya. ${ }^{28}$

Dalam hal ini, Kongres Ulama Perempuan mengeluarkan beberapa sikap keagamaan, sebagaimana berikut: 1) Bahwa perusakan alam yang mengakibatkan kemadharatan, atas nama apapun termasuk atas nama pembangunan, adalah haram secara mutlak. 2) Bahwa agama Islam harus mempunyai peran dalam upaya melestarikan alam. Karena maqāshid al-shar'iyah tidak hanya meliputi 5 hal (yaitu : hifž al-dīn, hifž al-nafs, hifz al-'aql, hifž al-nasl, \& hifz al$m \bar{a} l$ ), juga terdapat hifz al-bīah (menjaga kelestarian alam). 3) Negara harus bertanggungjawab penuh atas kelestarian lingkungan alam, sebagai penyebab pemiskinan terutama pada perempuan..$^{29}$

\section{Analisa Ekonomi terhadap Dampak Kerusakan Lingkungan Alam}

Fatwa dan Rekomendasi Ulama Perempuan Indonesia di atas, dalam Hasil Musyawarah Keagamaan Kongres Ulama Perempuan Indonesia No. 03/MKKUPI-1/IV/2017 tentang Perusakan Alam, hanya didasarkan pada pertimbangan nash-nash al-Qur'an. Karena dalam nash al-Qur'an sendiri berlimpah ayat yang menunjukkan bahwa manusia sebagai khalïfatullāh fi 'l-ard

\footnotetext{
27Tim KUPI, Dokumen Resmi Proses dan Hasil Kongres Ulama Perempuan Indonesia, 125.

${ }^{28}$ Tim KUPI, 126.

${ }^{29}$ Tim KUPI, 142-143.
} 
(pemimpin di atas bumi), larangan untuk berbuat kerusakan di atas bumi (fasad 'ala 'l-ard), dan perintah untuk memelihara dan perbaikan di atas bumi (al iṣlāḥ 'ala 'l-arḍ).

Penulis akan memberikan fokus pembahasan pada kerusakan lingkungan alam, melalui sudut pandang ekonomi. Sebagaimana disebutkan dalam alQur'an bahwa kerusakan di bumi dan di langit terjadi karena ulah tangan manusia. Dan sudah tentu kerusakan yang dilakukan oleh manusia atas bumi, pasti didasarkan pada motif ekonomi. Dampak ekonomi juga sangat terjadi, baik itu dihitung dari akibat kerusakan lingkungan maupun dihitung dari biaya sosial akibat kerugian yang dialami oleh kebanyakan orang.30 Seperti pembakaran hutan di Kalimantan, sangat memudahkan bagi seseorang atau badan usaha, tanpa harus repot mengeluarkan ongkos untuk menebang pohon, dan menggantikannya dengan industri tanaman ataupun hutan monokultur (hutan yang hanya ditanami oleh satu varietas jenis tanaman yang bisa digunakan sebagai bahan baku industri), seperti industri kertas ataupun industri kelapa sawit.

Kerusakan alam erat kaitannya dengan upaya memenuhi konsumen pasar. Misalnya permintaan atas karet, memungkinkan hutan disulap dengan tumbuhan monokultur karet. Demikian pula permintaan pasar yang tinggi atas komoditas sirip ikan hiu, sehingga bnyak nelayan yang melakukan pemburuan illegal terhadap satwa langka yang dilindungi. Di bidang pelayaran, kerusakan lingkungan hidup juga disebabkan oleh maraknya pemakaian jenis alat penangkapan ikan yang tidak ramah lingkungan atau penggunaan cantrang, sehingga merusak biota laut atau terumbu karang. ${ }^{31}$

Perusakan lingkungan alam demi mendapatkan bahan tambang. Mereka pada dasarnya, ingin menghasilkan pendapatan sebesar-besarnya, dengan menekan ongkos seminimal mungkin. Karena pada umumnya kerusakan lingkungan yang diakibatkan oleh suatu usaha, tidak dimasukkan sebagai salah satu variabel pengeluaran usaha. Mereka hanya memperhitungkan biaya pro-

\footnotetext{
${ }^{30} A k h m a d$ Fauzi, "Sinergi antara Pembangunan Ekonomi dan Pengelolaan Sumber Daya Alam dan Lingkungan," Jurnal Ekonomi Lingkungan 13, no. 2 (2009): 1-15, http://eslpascaipb.ac.id/ pdf/Sinegri antara Pembangunan Ekonomi dan Penelolaan Sumber Daya Alam dan Lingkungan.pdf.

${ }^{31}$ Yuyun Suprapti, Rudianto Syamsu Dhuha, and Miftachul Munir, "Persepsi Nelayan Cantrang terhadap Peraturan Menteri Kelautan Dan Perikanan Nomor 2 Tahun 2015," ECSOFiM: Economic and Social of Fisheries and Marine Journal 5, no. 1 (2017): 104-15, https://doi.org/10.21776/ ub.ecsofim.2017.005.01.10.
} 
duksi, biaya distribusi, biaya promosi, dan administrasi..$^{32}$ Tetapi tidak pernah mengeluarkan biaya atas kerusakan lingkungan yang telah mereka lakukan. Misalnya, biaya pencemaran air limbah industri di pinggir Sungai Jenes di Solo. Para pelaku usaha tidak mempedulikan berapa ongkos yang mereka bayar atas tercemarnya salah satu sungai di kota Bengawan tersebut.

Begitu juga dengan pencemaran logam berat di Teluk Buyat (Sulawesi Utara), pencemaran limbah industri di teluk jakarta, penggunaan merkuri utuk penambanan emas di Sungai Landak, menyebabkan terjadinya penyakit gatal di penduduk yang tinggal di daerah aliran sungai tersebut. ${ }^{33}$

Di negara-negara maju, para pelaku usaha memperhitungkan biaya kerugian yang dialami oleh pihak-pihak yang terdampak dari aktivitas usahanya, yang disebut dengan internalizing external cost. Mereka membayarkan biaya tersebut didasarkan atas valuasi (perhitungan), baik itu disebabkan karena pencemaran udara, pencemaran air, atau oleh karena kebisingan yang ditimbulkannya. Sedangkan di negara ini, suatu pihak dapat melakukan perusakan lingkungan dan berdampak pada masyarakat luas, tanpa memikirkan denda apa yang harus ia keluarkan atau hukuman apa yang harus ia terima.34

Secara kalkulasi ekonomi, maka pendapatan yang diperoleh oleh perseorangan lebih kecil nilainya, daripada total kerugian yang dialami oleh banyak orang. Misalnya keuntungan yang diperoleh dari illegal logging, mencapai puluhan triliun per tahun. Tetapi dampak negatif yang diakibatkan oleh tindakan illegal logging ini berjangka panjang, dengan banyaknya pihak yang berdampak. Seperti penghancuran hutan mangrove di sepanjang pesisir utara Jawa, untuk tambak udang, reklamasi, pembangunan pemukiman, dan industri, berdampak pada ribuan nelayan yang kesulitan mendapatkan ikan di perairan dekat pantai.

\footnotetext{
${ }^{32}$ Heri Sukendar-W., "Hubungan antara Kelestarian Ekonomi dan Lingkungan: Suatu Kajian Literatur," Binus Business Review 4, no. 2 (November 29, 2013): 841-50, https://doi.org/10.21512/ bbr.v4i2.1400.

${ }^{33}$ Tri Pranadji, "Keserakahan, Kemiskinan, dan Kerusakan Lingkungan," Analisis Kebijakan Pertanian 3, no. 4 (2005): 313-25, https://doi.org/10.21082/AKP.V3N4.2005.313-325.

${ }^{34}$ Sukendar-W., "Hubungan antara Kelestarian Ekonomi dan Lingkungan." 842.
} 


\section{F. Kesimpulan}

Ekonomi merupakan salah satu bagian terbesar dari motif tindakan yang diakukan oleh manusia. Selain juga motif lainnya, seperti motif pemenuhan kebutuhan biologis, dan psikologis. Banyak diantaranya, motif psikologi ataupun biologis berhimpitan dngan motif ekonomi, sehingga ketiganya sulit untuk dibedakan secara jelas. Seperti kasus pelacuran, tidak serta merta dianggap sebagai motif pemenuhan kebutuhan biologis semata, tetapi juga terdapat aspek pemenuhan kebutuhan ekonomi. Sehingga, pendekatan ekonomi untuk mengkaji permasalahan hal ini, terutama tentang kasus kekerasan seksual, tidak dapat digeneralisir, kecuali melihat kasus per kasus.

Kasus pelecehan seksual hampir dikatakan tidak ada kaitannya dengan faktor ekonomis. Tetapi kasus kekerasan dalam rumah tangga, sangat terkait dengan masalah ekonomi. Karena hal ini berkaitan dengan kemandirian perempuan dalam memenuhi kebutuhan diri dan anaknya, ketika mereka berpisah dengan suaminya.

Pada tema kerusakan alam yang diakibatkan oleh ulah manusia, hampir semuanya berkaitan dengan faktor ekonomi. Karena perilaku manusia dalam merusak lingkungan hampir bisa dipastikan untuk mengejar nilai ekonomis tertentu. Sehingga, motif tindakan seseorang dalam merusak alam dapat diperhitungkan secara ekonomi. Barang ekonomi apa yang mereka butuhkan dari alam? Berapa potensi keuntungan yang akan mereka raup, dan sebagainya. Bahkan perhitungan dampak kerusakan alam pun bisa diperhitungkan, sebagaimana yang dilakukan oleh negara maju. Berapa kerugian pencemaran air, udara dan kebisingan yang dihasilkan, harus menjadi variabel pembiayaan usaha seseorang.

Sedangkan pada tema pernikahan anak, secara umum ada keterkaitan antara faktor ekonomi (kemiskinan) dengan jumlah pernikahan anak. Tetapi tidak semua kasus pernikahan dini bisa diukur dengan sudut pandang ekonomi semata. Seperti kasus pernikahan dini yang diakibatkan oleh "Kehamilan Tak Diinginkan (KTD)", motif menjaga nama baik keluarga, lebih besar daripada sekedar motif ekonomi semata.[s] 


\section{Daftar Pustaka}

Asyari, Yusuf. "Nih 3 Rekomendasi Hasil Kongres Ulama Perempuan Indonesia." JawaPos.com - Berita di Sekitar Anda, 2017. https:// www.jawapos.com/jpg-today/29/04/2017/nih-3-rekomendasi-hasilkongres-ulama-perempuan-indonesia.

al-Bukhāry, Muhammad bin Ismāil bin Ibrāhīm bin al-Mughīrah. Ṣahīh alBukhāry. al-Maktabah al-Syamilah, n.d.

Burhanudin, Jajat, ed. Ulama Perempuan Indonesia. Gramedia, 2002.

Daniel, Everd Scor Rider, Nandang Mulyana, and Budhi Wibhawa. "Human Trafficking di Nusa Tenggara Timur." Share: Social Work Journal 7, no. 1 (2017): 21. https://doi.org/10.24198/share.v7i1.13808.

Endraswara, Suwardi. Metode, Teori, Teknik Penelitian Kebudayaan. Yogyakarta: Pustaka Widyatama, 2006.

Fauzi, Akhmad. "Sinergi antara Pembangunan Ekonomi dan Pengelolaan Sumber Daya Alam dan Lingkungan." Jurnal Ekonomi Lingkungan 13, no. 2 (2009): 1-15. http://eslpasca.ipb.acid/pdf/Sinegri antara Pembangunan Ekonomi dan Penelolaan Sumber Daya Alam dan Lingkungan.pdf.

Fauzia, Amelia, Jajat Burhanuddin, dan Oman Fathurahman. Tentang Perempuan Islam: Wacana dan Gerakan. Jakarta: Gramedia Pustaka Utama bekerja sama dengan Pusat Pengkajian Islam dan Masyarakat (PPIM), UIN Jakarta, 2004.

"Hasil Musyawarah Keagamaan Kongres Ulama Perempuan Indonesia No. 01/MK-KUPI-1/IV/2017 tentang Kekerasan Seksual 2017." Cirebon: KUPI, 2017.

Jamaa, La. "Perlindungan Korban Kekerasan dalam Rumah Tangga dalam Hukum Pidana Indonesia." Jurnal Cita Hukum 2, no. 2 (2014): 249-72. http://journal.uinjkt.ac.id/index.php/citahukum/article/view/1467.

Kusumawati, Aditya, Zahroh Shaluhiyah, dan Antono Suryoputro. "Tradisi Kekerasan Seksual sebagai Simbol Kekuasaan pada Anak Jalanan di Kota Semarang." Jurnal Promosi Kesehatan Indonesia 9, no. 1 (2016): 17-31. https://doi.org/10.14710/JPKI.9.1.17-31. 
Munawaroh, Siti. "Pekerja Seks Komersial (PSK) di Wilayah Prambanan, Kabupaten Klaten, Jawa Tengah.” Dimensia 4, no. 2 (2010): 69-82. https://journal.uny.ac.id/index.php/dimensia/article/view/3433.

Pranadji, Tri. "Keserakahan, Kemiskinan, dan Kerusakan Lingkungan." Analisis Kebijakan Pertanian 3, no. 4 (2005): 313-25. https://doi.org/10.21082/ AKP.V3N4.2005.313-325.

Satori, Rosidin, and Hasani. Liputan Media Kongres Ulama Perempuan Indonesia. Cirebon: KUPI, 2017.

Subdirektorat Statistik Rumah Tangga. Kemajuan yang Tertunda: Analisis Data Perkawinan Usia Anak di Indonesia. Jakarta: Badan Pusat Statistik, 2016.

Sukendar-W., Heri. "Hubungan antara Kelestarian Ekonomi dan Lingkungan: Suatu Kajian Literatur." Binus Business Review 4, no. 2 (November 29, 2013): 841-50. https://doi.org/10.21512/bbr.v4i2.1400.

Suprapti, Yuyun, Rudianto Syamsu Dhuha, dan Miftachul Munir. "Persepsi Nelayan Cantrang terhadap Peraturan Menteri Kelautan dan Perikanan Nomor 2 Tahun 2015." ECSOFiM: Economic and Social of Fisheries and Marine Journal 5, no. 1 (2017): 104-15. https://doi.org/10.21776/ ub.ecsofim.2017.005.01.10.

Teja, Muhammad. "Kondisi Sosial Ekonomi dan Kekerasan Seksual pada Anak." Majalah Info Singkat Kesejahteraan Sosial, May 2016.

Tim KUPI. Dokumen Resmi Proses dan Hasil Kongres Ulama Perempuan Indonesia. Cirebon: KUPI, 2017. 
This page intentionally left blank 